\title{
Article \\ Heterogeneous Electro-Fenton-like Designs for the Disposal of 2-Phenylphenol from Water
}

\author{
Antía Fdez-Sanromán, Rocío Martinez-Treinta, Marta Pazos (D), Emilio Rosales (D) and María Ángeles Sanromán* \\ CINTECX, University of Vigo, Campus As Lagoas-Marcosende, 36310 Vigo, Spain; \\ antia.fernandez.sanroman@uvigo.es (A.F.-S.); biosuv@uvigo.es (R.M.-T.); mcurras@uvigo.es (M.P.); \\ emiliorv@uvigo.es (E.R.) \\ * Correspondence: sanroman@uvigo.es; Tel.: +34-9868-123-83
}

Featured Application: Heterogeneous electro-Fenton-like processes based on catalyst and electrocatalyst using transition metals for 2-phenylphenol degradation.

\begin{abstract}
The hunt for efficient and environmentally friendly degradation processes has positioned the heterogeneous advanced oxidation processes as an alternative more interesting and economical rather than homogenous processes. Hence, the current study lies in investigating the efficiency of different heterogeneous catalysts using transition metals in order to prevent the generation of iron sludge and to extend the catalogue of possible catalysts to be used in advanced oxidation processes. In this study, nickel and zinc were tested and the ability for radical-generation degradation capacity of both ions as homogeneous was evaluated in the electro-Fenton-like degradation of 2-phenylphenol. In both cases, the degradation profiles followed a first-order kinetic model with the highest degradation rate for nickel $(1 \mathrm{mM})$ with 2-phenylphenol removal level of $90.12 \%$ and a total organic reduction near $70 \%$ in $2 \mathrm{~h}$. To synthesise the heterogeneous nickel catalyst, this transition metal was fixed on perlite by hydrothermal treatment and in a biochar or carbon nanofibers by adsorption. From the removal results using the three synthesized catalysts, it is concluded that the best catalysts were obtained by inclusion of nickel on biochar or nanofibers achieving in both with removal around $80 \%$ before $1 \mathrm{~h}$. Thus, to synthetize a nickel electrocatalyst, nickel doped nanofibers were included on carbon felt. To do this, the amount of carbon black, nickel nanofibers and polytetrafluoroethylene to add on the carbon felt was optimized by Taguchi design. The obtained results revealed that under the optimised conditions, a near-complete removal was achieved after $2 \mathrm{~h}$ with high stability of the nickel electrocatalyst that open the applicability of this heterogeneous system to operate in flow systems.
\end{abstract}

Received: 3 December 2021

Accepted: 16 December 2021

Published: 19 December 2021

Publisher's Note: MDPI stays neutral with regard to jurisdictional claims in published maps and institutional affiliations.

Keywords: nickel; zinc; 2-phenylphenol; heterogeneous; Fenton-like

\section{Introduction}

Nowadays, the need for various organic compounds to facilitate people's daily lives, such as pesticides, pharmaceuticals, cosmetics, etc., is a reality. Among these organic compounds, pesticides stand out because their use is essential to ensure the production and quality of foodstuffs demanded by the population [1-3].

In this study, the fungicide 2-phenylphenol, also called ortho-phenylphenol, has been chosen, which belongs to the hydroxybiphenyl chemical family [4]. The use of the fungicide 2-phenylphenol is mainly as disinfection, but it is also bactericide and virucide. As an example, in hospitals, shops and industries, it is generally used to disinfect surfaces and equipment, and in agriculture, it could be used to disinfect fruits, especially citrus fruits and pears, vegetables and eggs [5-7].

However, having all these advantages, the main problem is its appearance and persistence on the surface, such as food paper packages and canned soft drinks and aquatic 
environmental compartments [5]. In fact, since the early 2000s, it has been tracked down at low levels, in several environments: marine sediments and urban wastewaters [8], in sewage sludge (63-172 $\mu \mathrm{g} / \mathrm{kg})$, surface water $(47 \mathrm{ng} / \mathrm{l})$ and river sediments $(2-69 \mu \mathrm{g} / \mathrm{kg})$ from diverse streams and rivers in the state Baden-Württemberg (Germany) [9] or Bouregreg River (Morocco) at a concentration range of 54-257 ng/L [10].

According to the revision made, in 2003, by the World Health Organization (WHO), the permissible level in drinking-water is $0.1 \mathrm{mg} / \mathrm{L}$, at which toxic effects can be expected, was calculated from the acceptable daily intake (ADI) for humans of $0.4 \mathrm{mg} / \mathrm{kg}$ of body weight and this data has not been updated [11]. Recently, interesting research evaluated the effects of pesticides on humans, specifically on the younger population [12]. In this study, 703 infants were selected, who are under 1-year-old, and young children, being between 1 and 3 years old. It was noted that in more than $5 \%$ of them, pesticides could be detected, and the most common pesticide detected was 2-phenylphenol (18\%).

Several studies have reported its acute and chronic toxicity to creatures $[5,11,13,14]$. Indeed, the acute toxicity (LD50/LC50) in rats and mice have been determined in a range of concentration of $2880-3600$ and $3152-3499 \mathrm{mg} / \mathrm{kg}$ body weight, respectively [13]. In addition, other studies determined that, when rats were fed with 2-phenylphenol level of $0.5-4 \%$ in their diet, they suffer urinary bladder carcinoma [5].

These reported drawbacks encourage progress in emerging technologies to reduce this kind of pollutants from aquatic environmental compartments. These approaches include advanced oxidation processes stand out since they are green processes and very effective in the reduction of organic pollutants [15-18]. In addition, these types of processes can be performed in homogeneous and heterogeneous systems $[19,20]$.

Within each of these classes, multiple types can be also found, making advanced oxidation processes very versatile. Among them, electrochemical processes based on the use of electrical energy for the generation of radicals, such as hydroxyl, sulphate, etc., which have a high oxidising capacity and make it possible to break the bonds that form the molecules of these organic compounds $[15,21]$. Amongst, the electro-Fenton process represents an encouraging technology able to generate in situ hydrogen peroxide via cathodic reduction of oxygen (Equation (1)) and the generation of hydroxyl radical by Fenton reaction between the ferrous ion and hydrogen peroxide (Equation (2)) and the regeneration of ferric ion to ferrous ion on cathode (Equation (3)) to maintain the catalytic cycle of Fenton's reaction [15,21].

$$
\begin{gathered}
\mathrm{O}_{2}(\mathrm{~g})+2 \mathrm{H}^{+}+2 \mathrm{e}^{-} \rightarrow \mathrm{H}_{2} \mathrm{O}_{2} \\
\mathrm{Fe}^{2+}+\mathrm{H}_{2} \mathrm{O}_{2} \rightarrow \cdot \mathrm{OH}+\mathrm{OH}^{-}+\mathrm{Fe}^{3+} \\
\mathrm{Fe}^{3+}+\mathrm{e}^{-} \rightarrow \mathrm{Fe}^{2+}
\end{gathered}
$$

More recent approaches for the use of different transition metals as $\mathrm{Co}, \mathrm{Mn}, \mathrm{Cu}$, ... in several advanced oxidation processes for the removal of organic pollutants have been reported [22-25]. A clear example of the efficiency of these uses can be found in spent Lithium-ion batteries that contain $\mathrm{Li}, \mathrm{Ni}, \mathrm{Mn}, \mathrm{Al}$, and $\mathrm{Co}$, that after a simple washing-recycling process was employed as an easily recoverable catalyst for peroxymonosulfate (PMS) activation [26,27] with levels removal of more than $96 \%$ in more than 5 cycles of use [27].

These ions could be used instead of iron for the hydrogen peroxide decomposition and the reaction that takes place is similar to the classical Fenton process (Equation (4)) [28] In addition, in the electrochemical process, the $\mathrm{Me}^{(\mathrm{n}+1)+}$ could be regenerated to $\mathrm{Me}^{\mathrm{n}+}$ on the cathode, avoiding the generation of sludge and increasing the efficiency of this process $[28,29]$.

$$
\mathrm{Me}^{\mathrm{n}+}+\mathrm{H}_{2} \mathrm{O}_{2}+\mathrm{H}^{+} \rightarrow \mathrm{Me}^{(\mathrm{n}+1)+}+{ }^{\bullet} \mathrm{OH}+\mathrm{H}_{2} \mathrm{O}
$$

In recent years, the evaluation of various heterogeneous catalysts with application to electro-Fenton technology have been increasing number of studies. This increase is because 
it allows solving several drawbacks of the conventional process. In which is remarkable the requirements for catalyst amount optimization as well as the expansion of the working $\mathrm{pH}$ range or the operation in a flow system [30,31]. In this sense, iron and/or transition metals have been used to modify or functionalised cathode materials in the heterogeneous electro-Fenton process. This electrocatalytic material presents a dual benefit because the modified material could be used as a cathode and as a catalyst during the electrochemical treatment process [32-34].

To this day, studies about 2-phenylphenol degradation by advanced oxidation processes are limited in the literature, in which no one has evaluated the efficiency of electroFenton processes. Several of them were focused on the elimination of several compounds of the phenylphenol family by ultraviolet light (UV) and peroxide as an oxidising agent, achieving a level of $89 \%$, while in the other isomers the levels are in a range of $71-87 \%$ [35]. $\mathrm{TiO}_{2}$ and B-doped $\mathrm{TiO}_{2}$ catalysts were synthesised and several pesticides (2-methyl-4chlorophenoxyacetic acid, diuron, ter-buthylazine and o-phenylphenol) were eliminated by ozonation and photocatalytic processes alone or in combination under simulated solar irradiation. Having been determined combination of processes led to faster mineralization of the pollutants mixture keeping around $75 \%$ after to perform three successive cycles [36]. Recently, selective degradation of o-phenylphenol was obtained by applying $\mathrm{N}$-doped $\mathrm{TiO}_{2}$ photocatalysts under simulated solar light irradiation showing a degradation efficiency of around $46 \%$ [24].

In this context, this work aimed to assess the degradation of 2-phenylphenol by electroFenton-like process, using as a catalyst transition metal ion (nickel and zinc). Based on the preliminary results, the synthesis of new catalysts and electrocatalyst (used as the cathode) is carried out to open the possibility of using this degradation process in a heterogeneous mode. According to our knowledge, this research is one of the first endeavours where nickel and zinc are used as heterogeneous catalysts and electrocatalysts in Fenton processes. In this situation, the present report intends to establish the use of these transition metals as an alternative to the conventional advanced oxidation processes for 2-phenylphenol removal, using different heterogeneous designs (catalysts and electrocatalyst).

\section{Materials and Methods}

\subsection{Pollutants}

Synthetic polluted effluents were obtained using ultrapure-water at desired concentrations of 2-phenylphenol (Sigma-Aldrich, Barcelona, Spain). Nickel (II) chloride hexahydrate, zinc (II) sulfate heptahydrate, anhydrous sodium sulphate, expanded perlite beads (grade 5), carbon black, polytetrafluoroethylene (PTFE) and carbon nanofiber were purchased from Sigma-Aldrich. Carbon-felt RVG 2000 and boron-doped diamond (BDD) were supplied by Carbon-Lorraine and Condias, respectively.

\subsection{Electrochemical Processes}

Experiments were performed in a $250 \mathrm{~mL}$ electrochemical undivided cylindrical cell (Figure 1) with a solution volume of $150 \mathrm{~mL}$ of 2-phenylphenol solution $25 \mathrm{mg} / \mathrm{L}$ with $10 \mathrm{mM} \mathrm{Na}_{2} \mathrm{SO}_{4}$ as a supporting electrolyte. The initial solution $\mathrm{pH}$ was 3 by acidification with $0.1 \mathrm{M} \mathrm{H}_{2} \mathrm{SO}_{4}$. BDD $(3.5 \times 2.0 \times 0.2 \mathrm{~cm})$ as anode BDD and different cathodes (described in the following section) were connected to a direct current power supply (HP model 3662) at different current intensities. To in situ electrogeneration of hydrogen peroxide, continuous compressed air was bubbled $(0.5 \mathrm{~L} / \mathrm{min})$ on the cathode surface and the solution was stirred to prevent concentration gradients into the bulk solution. Electric parameters were recorded with a digital multimeter (BRYMEN BM-257). Anodic oxidation was performed using electrodes BDD and carbon felt without airflow to limit the hydrogen peroxide generation. In the homogeneous electro-Fenton-like process nickel and zinc was added in a range of 1-5 mM. In a heterogeneous process, several catalysts were synthesised as is described in the next section. 


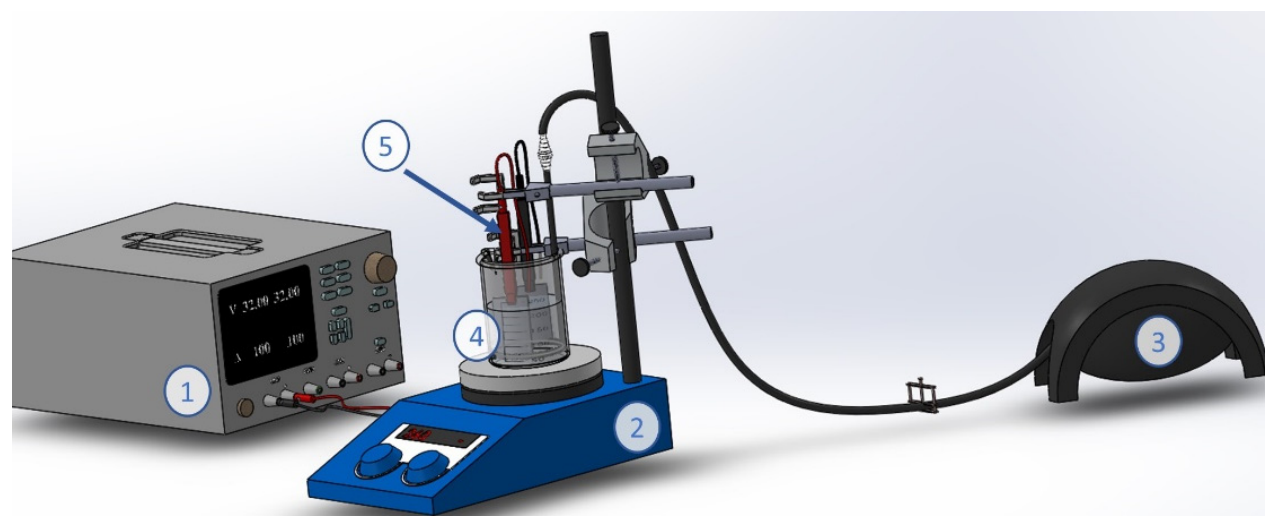

Figure 1. Experimental device for anodic oxidation and electro-Fenton-like process. (1) current power supply, (2) magnetic plate, (3) air pump, (4) cylindrical electrochemical cell and (5) electrodes.

\subsection{Heterogeneous Catalyst}

Several transition metal catalysts were synthesised using different materials and techniques. Thus, nickel perlite was obtained by inclusion of $20 \mathrm{~g}$ of perlite in a $200 \mathrm{~mL}$ of nickel solution in a Teflon autoclave reactor, which was kept in a muffle (Thermolyne F3040CM-33 Fisher Scientific, Madrid, Spain) at $200{ }^{\circ} \mathrm{C}$ during $1 \mathrm{~h}$ for its hydrothermal treatment and finally was cooled at room temperature, filtered, cleaned with ultrapurewater and dried at $105^{\circ} \mathrm{C}$ for $12 \mathrm{~h}$. Nickel nanofibers were manufactured by immersion of carbon nanofibers in a nickel solution at $70{ }^{\circ} \mathrm{C}$ and $\mathrm{NaOH}(5 \mathrm{M})$ was added dropwise to generate the nanoparticles. Rice bran biochar was produced by thermal decomposition of grinded and sieved rice bran material (size lower than $0.250 \mathrm{~mm}$ ) at $320{ }^{\circ} \mathrm{C}$ for $30 \mathrm{~min}$ under an inert nitrogen atmosphere by heating $10^{\circ} \mathrm{C} / \mathrm{min}$ [37]. Then, it was added in nickel solution for $12 \mathrm{~h}$. In both cases, after immersion in the solution, the material was cleaned with ultrapure-water and dried at $60{ }^{\circ} \mathrm{C}$ for $24 \mathrm{~h}$.

\subsection{Cathodes}

Different cathodes were used: (i) an unmodified carbon felt cute in rectangular size $5 \times 2.5 \mathrm{~cm}$ and (ii) functionalised cathodes. In the last, previously the carbon felt was cleaned with acetone and, thereafter, with ultrapure-water using an ultrasonic bath for $1 \mathrm{~h}$ (Fisherbrand FB11203, Fisher Scientific, Madrid, Spain) and dried at $60{ }^{\circ} \mathrm{C}$ for $24 \mathrm{~h}$. After that, nickel nanofibers were included by immersion of carbon felt in a dispersed solution that contained carbon black, carbon nanofibers and PTFE in a solution 1:2.5 ethanol:ultrapure-water. In this study, the proportion of each component was optimized by the Taguchi design experiment (see Section "Taguchi Design Experiment"). Thereafter, following the procedure described in the literature [38,39], the material was sonicated for $30 \mathrm{~min}$ and dried at $80{ }^{\circ} \mathrm{C}$ for $12 \mathrm{~h}$, and as a final point annealed at $360{ }^{\circ} \mathrm{C}$ for $30 \mathrm{~min}$.

\section{Taguchi Design Experiment}

This method is based on the orthogonal array experimental design proposed by Taguchi and allows the study of the effect of different parameters employing a minimum number of runs. It is a simple and effective way for the identification and optimisation of the parameter conditions on the selected response thought the use of ANOVA as analysis tool.

In the present study, the Taguchi experiment was used for the selection of significant components and their optimisation in the electrocatalyst composition (A: carbon black, B: nickel loaded nanofibers and C: PFTE content) applied for the degradation of the selected pollutant. The parameters affecting the development of the process and their values have been identified in the Table 1 . 
Table 1. Screening experiment parameters and level.

\begin{tabular}{cccc}
\hline Parameter & A & B & C \\
\hline & Carbon Black $(\mathrm{g})$ & Nickel nanofibers $(\mathrm{g})$ & PTFE $(\mathrm{g})$ \\
\hline Level 1 & 0.1 & 0.4 & 2.5 \\
Level 2 & 0.3 & 0.6 & 4.2 \\
\hline
\end{tabular}

The performance of the method outputs is optimized in relation to the response's signal/noise ratio $(\mathrm{S} / \mathrm{N})$ which decreases the variability of the process. In this method, $\mathrm{S} / \mathrm{N}$ represents the measurement of the deviation of the response from the desired value. A lower variability in the process is ensured through maximizing the $\mathrm{S} / \mathrm{N}$ ratio, and in this study, the larger-the-better category (Equation (5)) was selected.

$$
\mathrm{S} / \mathrm{N}=-10 \cdot \log \left(1 / \mathrm{n} \sum 1 / \mathrm{y}^{2}{ }_{\mathrm{i}}\right)
$$

where $y_{i}$ is the response and $n$ is the number of experiments.

\subsection{Sample Preparation and Analytical Methods}

Periodically, samples were taken from the electrochemical cell and centrifuged at 10,000 rpm for $10 \mathrm{~min}$. The liquid was used to determine the $\mathrm{pH}$, 2-phenylphenol, hydrogen peroxide, total organic carbon (TOC) and transition metals concentration.

\subsubsection{2-Phenylphenol Concentration}

2-phenylphenol degradation was determined by HPLC and spectrophotometrically. For HPLC determination, 2-phenylphenol concentration decrease was measured with an Agilent 1100 HPLC equipped with Diode Array Detector and using a Zorbax Eclipse XD8-C8 reverse-phase column $(150 \times 4.6 \mathrm{~mm}$ i.d. $5 \mu \mathrm{m})$. Mobile phase composed of water:acetonitrile (40:60) was pumped in isocratic mode at $1 \mathrm{~mL} / \mathrm{min}$ for $20 \mathrm{~min}$. Separation was carried out at room temperature and the column effluent was monitored spectrophotometrically at $252 \mathrm{~nm}$ wavelength. Prior to chromatographic analysis, all samples were filtered through $0.45 \mu \mathrm{m}$ PVDF filters. Spectrophotometric measurements were performed with a GENESYS 150 UV-Vis Spectrophotometer from 240 to $350 \mathrm{~nm}$, and the pollutant removal was associated with the area under curve decrease and expressed in terms of percentage in relation to the initial sample.

\subsubsection{Hydrogen Peroxide Concentration}

It was determined according to the Titanium oxalate method developed by Sellers [40]. In this method, $2 \mathrm{~mL}$ of filtrated sample were mixed with $0.25 \mathrm{~mL}$ of sulphuric acid solution (1:17), $0.2 \mathrm{~mL}$ of potassium titanium oxide oxalate dihydrate $(50 \mathrm{~g} / \mathrm{L})$ and $0.05 \mathrm{~mL}$ of distilled water for a final volume of $2.5 \mathrm{~mL}$. After $5 \mathrm{~min}$ of reaction, the generation of yellow-orange titanium (IV) peroxide complex was spectrophotometrically measured at the maximum absorbance at $400 \mathrm{~nm}$ in a GENESYS 150 UV-Vis Spectrophotometer (Thermo Fisher Scientific, Madrid, Spain). Reagents were provided by Sigma-Aldrich (Barcelona, Spain).

Current efficiency for hydrogen peroxide production (CE, \%) and electric energy consumption (EEC, $\mathrm{kWh} / \mathrm{kg}$ ) was determined following Equations (6) and (7) [41]:

$$
\begin{aligned}
& \mathrm{CE}(\%)=\frac{\mathrm{n} \cdot \mathrm{F} \cdot \mathrm{C}_{\mathrm{H}_{2} \mathrm{O}_{2}} \cdot \mathrm{V}}{\int_{0}^{t} \mathrm{Idt}} \cdot 100 \\
& \mathrm{EEC}=1000 \cdot \mathrm{U} \cdot \mathrm{I} \cdot \mathrm{t} / \mathrm{C}_{\mathrm{H} 2 \mathrm{O} 2} \cdot \mathrm{V}
\end{aligned}
$$

where $\mathrm{n}(=2)$ is the number of electrons transferred for oxygen reduction to hydrogen peroxide, F: Faraday constant, I: current intensity (A), t: time (s), $\mathrm{C}_{\mathrm{H} 2 \mathrm{O} 2}$ : hydrogen peroxide concentration $(\mathrm{mg} / \mathrm{L})$ and $\mathrm{V}$ : volume of the solution and $\mathrm{U}$ : voltage $(\mathrm{V})$. 


\subsubsection{Metal Leaching Concentration}

The metal concentration was monitored by Atomic Absorption Spectroscopy (Agilent 240FS) (C.A.C.T.I., University of Vigo).

\subsubsection{TOC Concentration}

Mineralization degree was determined via combustion by multi N/C 3100 Autoanalyzer (Analytik Jena) coupled with a nondispersive infrared (NDIR) detector (C.A.C.T.I. University of Vigo).

\subsubsection{Material Characterization}

For the characterization of the different synthesised materials, scanning electron microscopy (SEM) images were used to know the morphological characterization of catalyst and electrocatalyst. SEM images and Energy Dispersive Microanalysis (EDS) were performed on a JEOL JSM-6700F equipped with an EDS Oxford Inca Energy 300 SEM using an accelerating voltage of $20 \mathrm{kV}$ (Electron Microscopy Service, C.A.C.T.I., University of Vigo, Spain).

The hydrophilicity/hydrophobicity of the prepared electrodes was determined based on the contact angle. For this purpose, a Mobile Drop Analyzer (Kruss) was used and the contact angle between a water drop (volume $0.005 \mathrm{~mL}$ ) and the electrode material was measured.

\section{Results}

\subsection{Screening of Transition Metals in Homogeneous Electro-Fenton-like Process}

Initially, nickel and zinc ions were evaluated in the electro-Fenton-like process as catalysts for generation of hydroxyl radicals from hydrogen peroxide, which is produced in an electrochemical cell by two-electron reduction of oxygen on a carbonous cathode surface using electrical energy to overcome the unfavourable reactions [42]. In this study, a carbon felt cathode and BDD anode were used, and the hydrogen peroxide production was evaluated at different current intensities. This parameter affects the efficiency of the electro-Fenton process due to the oxygen reduction and generation of hydrogen peroxide on the cathode are directly related to the applied current. The continuous production of hydrogen peroxide at two current intensities (100-300 mA) showed that the efficiencies for the production were increased with the reduction of the current intensity. In both cases, the generation reached an apparent steady-state level after $60 \mathrm{~min}$, which could be explained by the in situ decomposition of hydrogen peroxide [43]. In addition, the energy consumption of $100 \mathrm{~mA}(161 \mathrm{kWh} / \mathrm{kg})$ was lower than that of $300 \mathrm{~mA}(998.79 \mathrm{kWh} / \mathrm{kg})$ after $60 \mathrm{~min}$. On the other hand, the current efficiency proved a better efficiency in the hydrogen peroxide production at a lower intensity ( 9.36 and 1.93 at $60 \mathrm{~min}$ for 100 and $300 \mathrm{~mA}$, respectively).

Based on these results a current intensity of $100 \mathrm{~mA}$ was selected to evaluate the ability of the different transition metals (nickel and zinc) in the degradation of 2-phenylphenol. In the electro-Fenton the optimal concentration of used iron catalyst is lower than the conventional Fenton process, thus in the Fenton process is required catalyst concentration in a range of $\mathrm{g} / \mathrm{L}$, while in the electro-Fenton process is $\mathrm{mg} / \mathrm{L}$ [44]. Moreover, the catalyst concentration is one of the key parameters to control the production of hydroxyl radical and the efficiency of the electro-Fenton process [31]. For this reason, as an attempt to optimize the electro-Fenton process, three concentrations $(1,3$ and $5 \mathrm{mM})$ of each transition metal ions were tested.

Figure 2a shows the degradation profiles of 2-phenylphenol in the three electro-Fenton tests carried out in comparison to the anodic oxidation test, used as control experiment. BDD electrodes have great characteristics that distinguish them from other materials, such as high oxygen evolution potentials, inert surface with low adsorption and very low double layer capacitance and background current. Thanks to its properties, BDD anodes attain higher oxidation rates and mineralization efficiencies, producing ${ }^{\bullet} \mathrm{OH}$ from water 
electrolysis (Equation (8)) that are strongly adsorbed on its surface and unselectively attack the 2-phenylphenol.

$$
\mathrm{BDD}+\mathrm{H}_{2} \mathrm{O} \rightarrow \mathrm{BDD}\left({ }^{\bullet} \mathrm{OH}\right)+\mathrm{H}^{+}+\mathrm{e}^{-}
$$

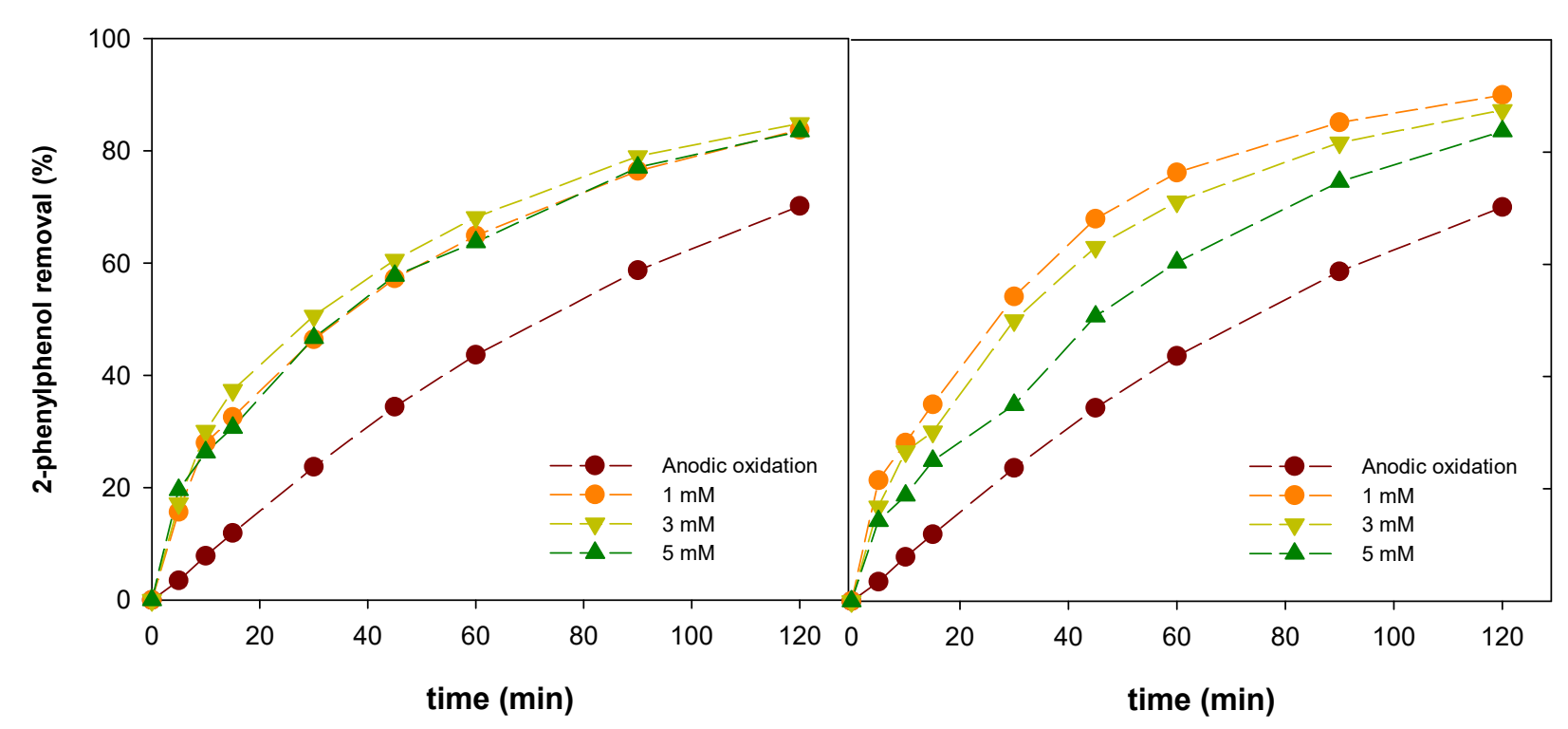

Figure 2. Profiles of 2-phenylphenol removal in anodic oxidation and electro-Fenton-like using zinc (right) and nickel (left) at $1 \mathrm{mM}(\bullet), 3 \mathrm{mM}(\boldsymbol{\nabla})$ and $5 \mathrm{mM}(\boldsymbol{\Delta})$.

As is shown in Figure 2, anodic oxidation achieved a 2-phenylphenol degradation level of around $70.15 \%$, meanwhile, in the electro-Fenton treatment tests, the degradation increased to a range of $80-90 \%$, which represents an increase in efficiency of more than $10 \%$. Concerning the concentration of $\mathrm{Ni}$ used, the percentage of degradation is around $5 \%$ between each of them, increasing the degradation level from 5 to $1 \mathrm{mM}$ of Ni. These presented experimental data seem to reveal that 2-phenylphenol removal is described by a kinetic model of first-order (Equation (9)):

$$
-\frac{\mathrm{dC}}{\mathrm{dt}}=\mathrm{k} \cdot \mathrm{C}
$$

where $\mathrm{C}(\mathrm{mg} / \mathrm{L})$ : measured 2-phenylphenol concentration along the reaction time, $\mathrm{t}(\mathrm{min})$ and $\mathrm{k}$ : kinetic constant $\left(\mathrm{min}^{-1}\right)$.

Table 2 summarizes the kinetic values and TOC reduction after $120 \mathrm{~min}$ of all tests performed. It should also be noticed that the test using nickel as catalyst, which gives the highest reaction rate, was $1 \mathrm{mM}$ with a value 2.5 times higher than the constant of anodic oxidation. This electro-Fenton-like process shows a similar degradation rate in comparison with other previous studies using other more expensive degradation processes such as ozonation or UVC irradiation combined with ozonation processes [45]. Analogous to the electro-Fenton process with iron, the decrease in the efficiency with the increase of the catalyst could be due to the scavenging effect of an excess of nickel that will produce an excess of $\mathrm{Ni}^{3+}$, which react with hydrogen peroxide to produce hydroperoxyl radical of less oxidation capability than hydroxyl radical. Another reaction that can take place when an excess of $\mathrm{Ni}^{2+}$ is present is its reaction with hydroxyl radicals, decreasing the concentration of both and reducing the degradation reaction rate [21]. 
Table 2. Parameter of first order reaction kinetic model (Equation (9)) fitting to the experimental data and TOC reduction after $2 \mathrm{~h}$ of treatment.

\begin{tabular}{ccccc}
\hline Transition Metal & Concentration $(\mathbf{m M})$ & $\mathbf{k}\left(\mathbf{m i n}^{-\mathbf{1}}\right)$ & $\mathbf{R}^{\mathbf{2}}$ & TOC Reduction $\mathbf{( \% )}$ \\
\hline Anodic oxidation & 0 & 0.0098 & 0.9989 & 44.62 \\
\hline \multirow{2}{*}{ Nickel } & 1 & 0.025 & 0.9924 & 69.08 \\
& 3 & 0.0218 & 0.9829 & 66.67 \\
Zinc & 5 & 0.0152 & 0.9855 & 64.60 \\
& 1 & 0.0189 & 0.9952 & 60.37 \\
& 3 & 0.0208 & 0.9954 & 64.36 \\
\end{tabular}

Similarly, the electro-Fenton-like test using zinc as homogeneous catalyst showed also better results than anodic oxidation (Figure 3). Concerning the zinc concentration, in this case, the differences among them are minimal, achieving the highest reaction rate at a zinc concentration of $3 \mathrm{mM}$ (Table 2). However, the maximum removal was around $84.88 \%$ with a corresponding $64.36 \%$ TOC reduction after $120 \mathrm{~min}$, values that were lower than the obtained using nickel as a catalyst with 90.12 and $69.08 \%$ of pollutant removal and TOC reduction, respectively. Thus, the best performance was attained when the electroFenton process was performed with nickel and the next assays were carried out using this transition metal ion.

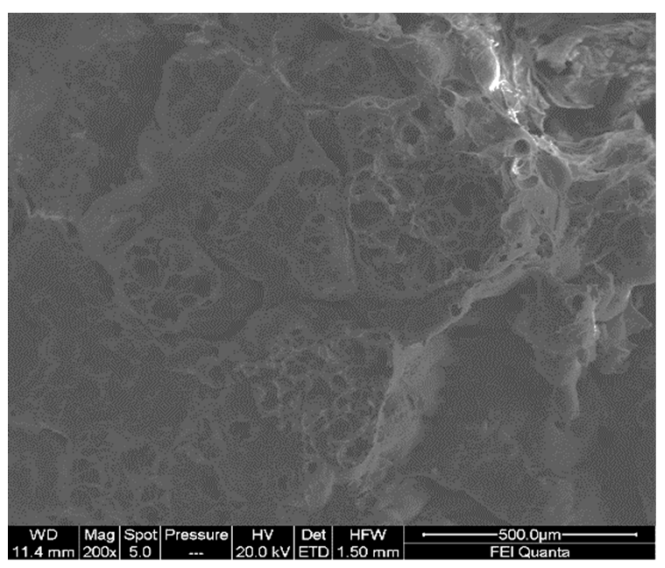

(a)

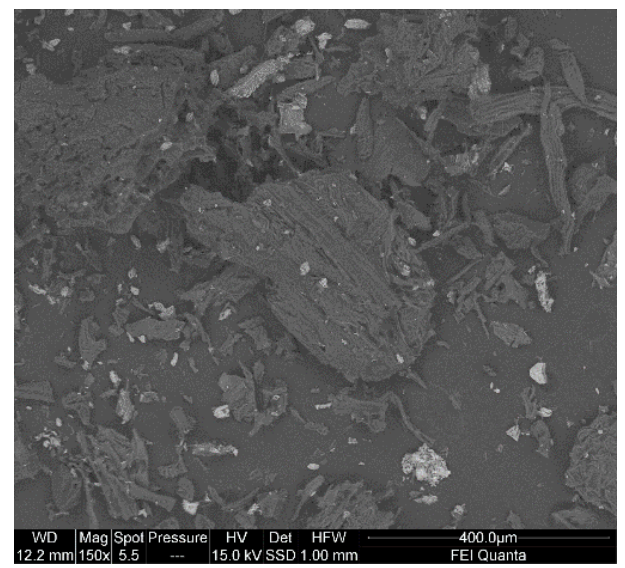

(b)

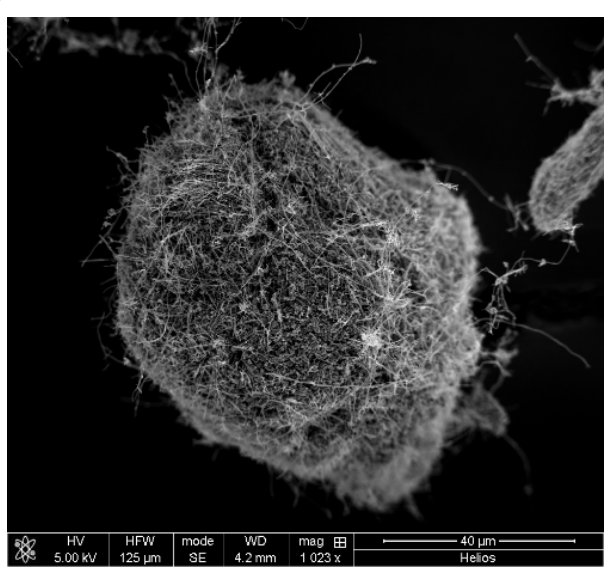

(c)

Figure 3. SEM images of (a) perlite, (b) biochar and (c) carbon nanofibers. 


\subsection{Heterogeneous Nickel Catalyst}

Once established nickel as the best electro-Fenton-like catalyst, several heterogeneous catalysts were synthesised in order to allow the operation in a flow system process.

As was described in material and methods, the nickel was included in different materials such as perlite, biochar or nanofibers by hydrothermal and adsorption treatments (Figure 3). Perlite was selected because it has been proved to be a good material for the fixation of metals such as iron by hydrothermal treatment [46]. In addition, this material has a floating characteristic that allows the catalyst to be on the liquid surface so that it can be recovered very easily [47]. Both of these characteristics are considered suitable for use in the design of a heterogeneous system electro-Fenton treatment. Biochar and nanofiber are materials with higher surface area and porosity [33,48], that allow the retention of metal ions by adsorption that can be used as a catalyst. The morphology and structural characteristics were determined by SEM, which confirmed the high porosity of these materials that favours the contact of the catalyst with the hydrogen peroxide increasing the removal rate [37]. Attending at Figure 3, it can be observed that the perlite presents a high amount of macropores for the fixation of the metal as suggested previously; however, biochar and carbon nanofibers have a superior surface area (45 and $54 \mathrm{~m}^{2} / \mathrm{g}$ ) with small-sized pores.

Figure 4 shows the 2-phenylphenol removal profiles using the different catalysts tested in this study. It is clear that with catalyst supported in nanofiber and biochar the removal levels achieved after $5 \mathrm{~min}$ are quite similar (70-75\%) which could be explained by the adsorption of the pollutant in the carbonaceous materials (biochar and nanofiber).

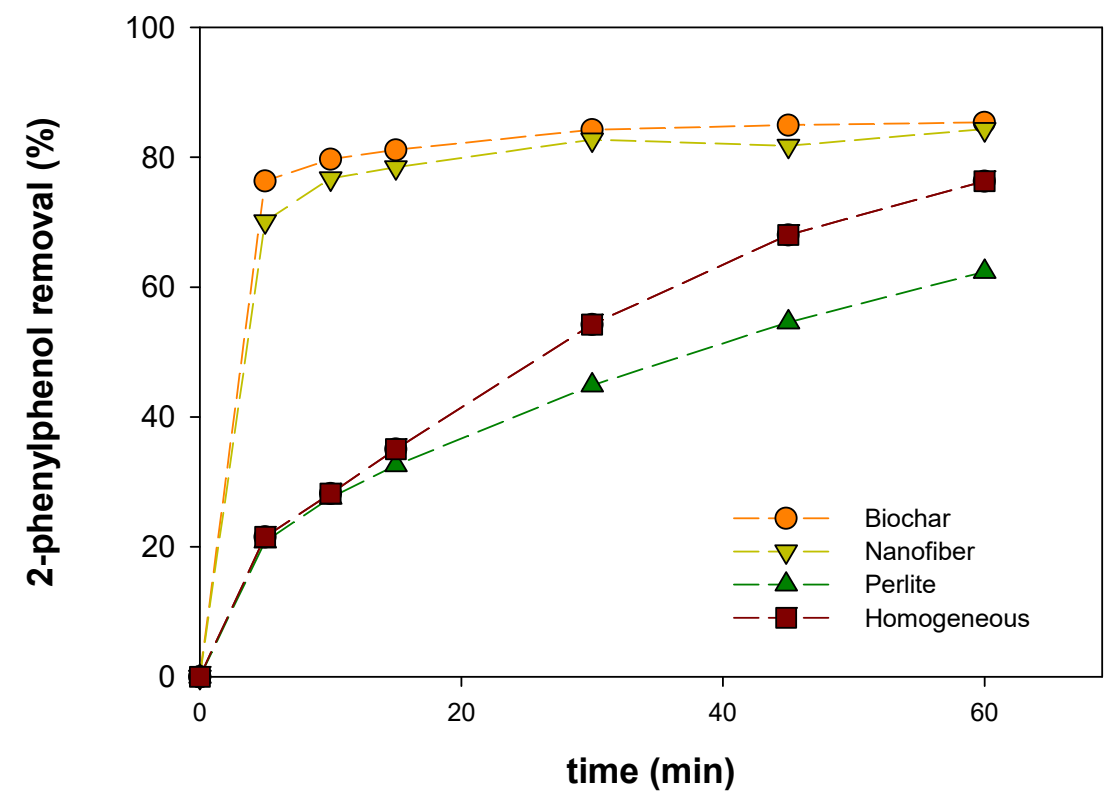

Figure 4. Profiles of 2-phenylphenol removal (\%) in different heterogeneous electro-Fenton-like and homogeneous electro-Fenton processes.

To elucidate this hypothesis, the adsorption of 2-phenylphenol in these materials was evaluated and compared with the electro-Fenton process. It was detected a high adsorption rate on carbonaceous materials, with levels around $60 \%$ after $5 \mathrm{~min}$, achieving the maximum removal (76\%) after $60 \mathrm{~min}$. These values are lower than obtained when the electro-Fenton process was evaluated. Desorption process was accomplished in order to elucidate if the 2-phenylphenol was adsorbed upon the carbonous materials after the adsorption and electro-Fenton process. Desorption of 2-phenylphenol from nickel catalysts with acetonitrile did not show a residual concentration, however from nanofiber and biochar used in the adsorption test was possible the total recovery of the adsorbed pollutant in the acetonitrile solution. 
These results confirm that the electro-Fenton treatment with this kind of catalyst is an efficient process for the disposal of pollutants that takes place in two steps: adsorption and oxidation. Even when adsorption has an important role, the adsorbed 2-phenylphenol was finally oxidized, resulting in a high removal from the bulk solution. This behaviour is in accordance with other previous studies in which the combination of adsorption and oxidation process had been detected. Thus, the efficiency of a hybrid process such as adsorption-Fenton oxidation using granular activated carbon showed, that this two-step process is an excellent combination for the effective removal of bisphenol A [49]. This synergistic interaction of adsorption and photocatalysis process has been considered in several studies as one of the most efficient techniques for environmental purification of wastewater [50,51]. Recently, doped porous carbon prepared by in-situ doping after carbonization of nitrogen-containing Metal-organic framework materials showed high efficiency for removal of tetracycline hydrochloride as a catalyst of PMS advanced oxidation process. It was demonstrated that the high degradation level achieved is closely related to the adsorption and catalytic performance of the catalyst [52]. Thus, the capability of carbonaceous catalysts to adsorb the target pollutant makes them excellent candidates for the two-step process of treating organic pollutants. In the literature, there are several studies in which electro-Fenton-process was used to regenerate spent adsorbent-like granular activates carbon [53,54], biochar [37] or aerogels used as adsorbents of pharmaceuticals pollutants $[55,56]$.

In addition, no nickel leaching was detected which confirms that the use of these carbonaceous materials as a catalyst is a good option to design a system to operate in a flow system avoiding the presence of nickel in the output stream.

\subsection{Heterogeneous Nickel Electrocatalyst}

Nowadays, a challenge of the modern electro-Fenton systems is to improve the characteristics of the cathodes to enhance hydrogen peroxide production. In this sense, several authors have focused their studies on the evaluation of several cathode modification strategies that can improve its properties and increase electric conductivity [57,58]. Among the wide range of approaches reported for the enhancement of the production, cathodes synthesised by merging carbonaceous materials and Teflon (polytetrafluoroethylene or PTFE) have achieved interesting results $[59,60]$.

In addition, to improve the electro-Fenton process, the inclusion of metals in the cathode can act as a heterogeneous catalyst with the capacity to react with electrogenerated hydrogen peroxide [31,61,62]. In this context, the inclusion of nanofibers doped with nickel has been tested to perform the heterogeneous electro-Fenton process. Due to a large number of experiments need to evaluate the effect of cathode composition, in this study, a Taguchi design was used to reduce the number of trials required to obtain a valid conclusion [63]. Taguchi uses orthogonal matrices, which organise the variables that affect the process and their levels, in the most likely to affect the process. In addition, it offers the opportunity to reduce the number of experiments by testing pairs of combinations, saving time and resources. It allows the calculation of a signal-to-noise ratio $(\mathrm{S} / \mathrm{N})$ based on experimental data, which defines the best experimental conditions, considering product quality or process performance within the range of process performance within the experimental range tested.

In this study, the cathodes were prepared by immersion of carbon felt in a dispersion solution of ethanol:ultrapure water that contained carbon black, nickel nanofibers and PTFE (Figure 5). In this study, the Taguchi method was used to investigate the effect of three operating parameters to obtain an optimal process within the evaluated range. The selected variables were A: carbon black, B: nickel nanofibers and C: PTFE and the used concentrations were summarised in Table 2. 


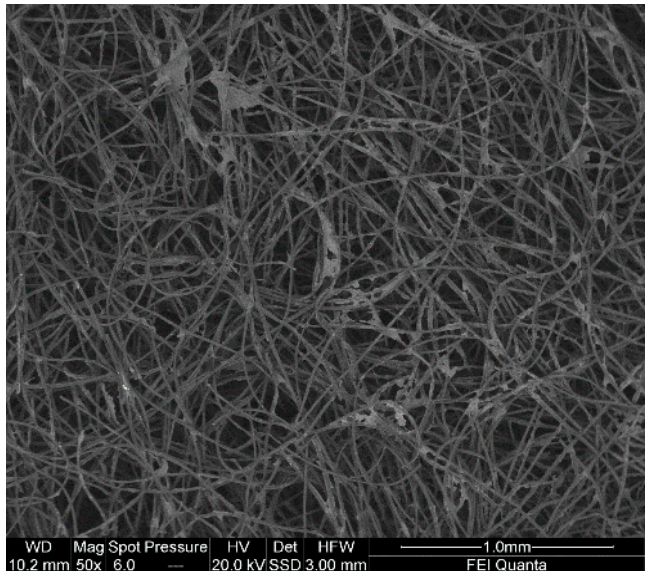

(a)

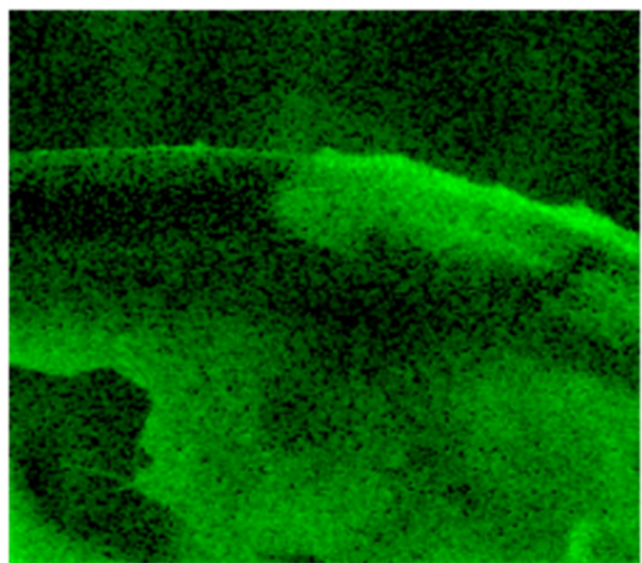

$\longdiv { 1 0 \mu \mathrm { m } }$

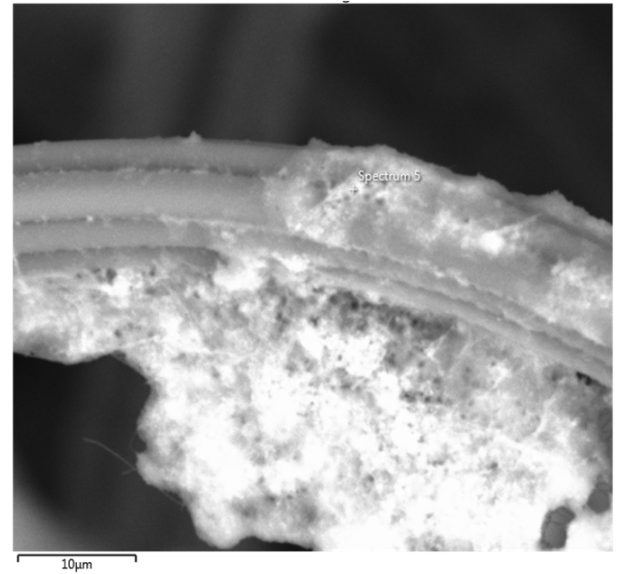

(b)

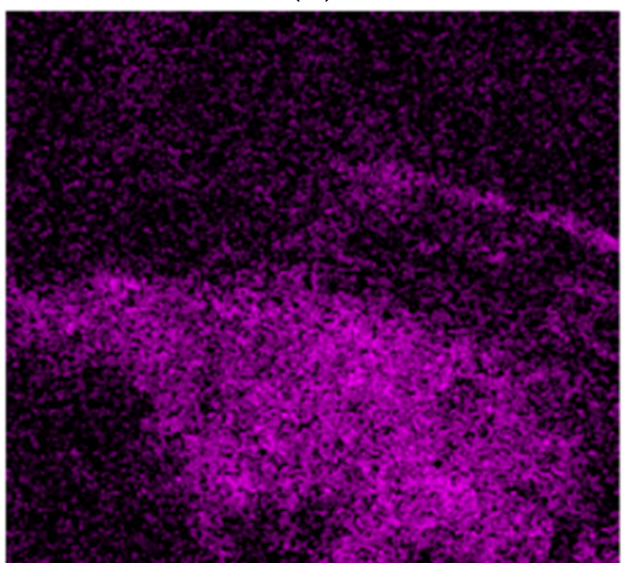

$\longdiv { 1 0 \mu \mathrm { m } }$

(c)

(d)

Figure 5. Detailed SEM image of an electrocatalyst containing carbon black, nanofibers, PTFE and nickel (a,b) and EDS analysis: fluorine (c) and nickel (d).

The current intensity was also tested since depending on the composition, the response of the prepared electrodes could be different about carbon felt cathode. Thus, the Taguchi method to ascertain the significance of each of the factors chosen in the hydrogen peroxide production was evaluated operating at 100 and $300 \mathrm{~mA}$.

The effect of the input variables on the hydrogen peroxide has been determined by the $\mathrm{S} / \mathrm{N}$ ratio with the larger-the-better criteria and the attained response values were therefore converted into S/N. As an example, Figure 6 shows the main effect plots for the response at intensity current of $100 \mathrm{~mA}$. Thus, the strongest influence is the nickel nanofibers, followed by carbon black and PTFE. Moreover, the main effect plots determine the optimum factor levels. As can be seen, $\mathrm{A}_{2} \mathrm{~B}_{2} \mathrm{C}_{1}$ are the optimal condition operating at both current intensities. These improvements of hydrogen peroxide could be attributed to the change in the surface cathode with, for example, the formation of microporous by deposition of carbon black and nanofibers.

In Figure 7, the profiles of produced hydrogen peroxide and 2-phenylphenol removal operating with the optimized cathode at 100 and $300 \mathrm{~mA}$ are shown. 


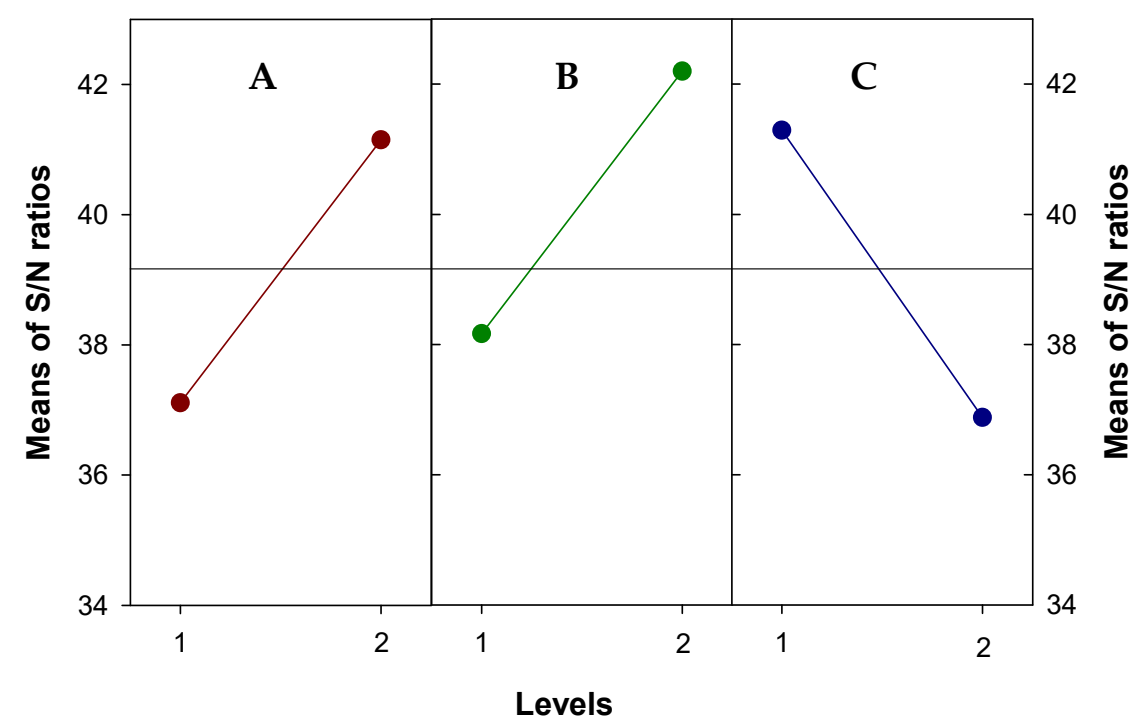

Figure 6. Main effects plot for $\mathrm{S} / \mathrm{N}$ ratios with the larger-the better criteria of screening experiment yield. Responses of hydrogen peroxide produced at $100 \mathrm{~mA}$. (A: carbon black, B: nickel loaded nanofibers and C: PFTE content).

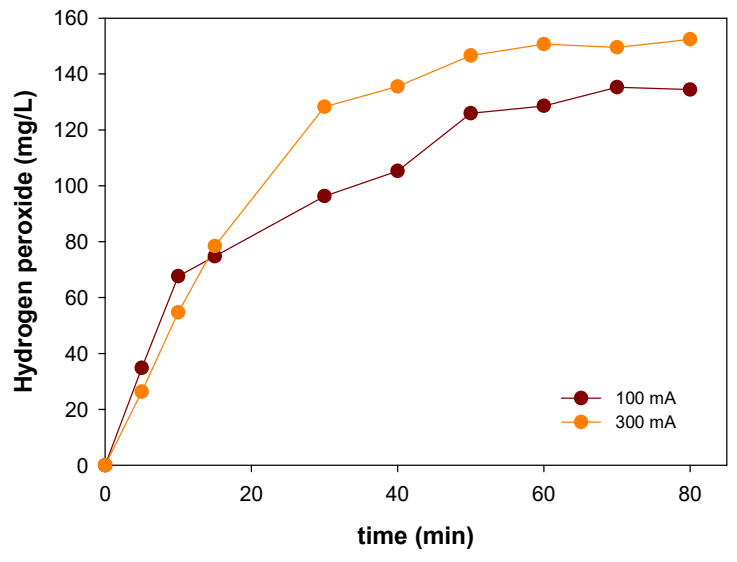

(a)

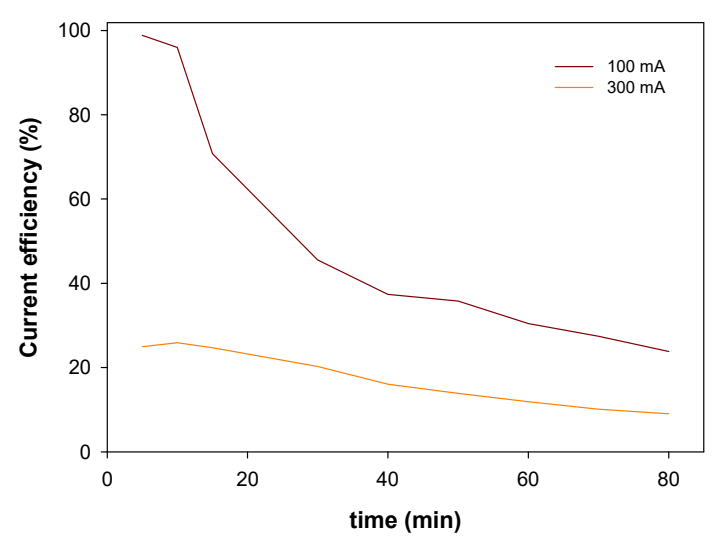

(c)

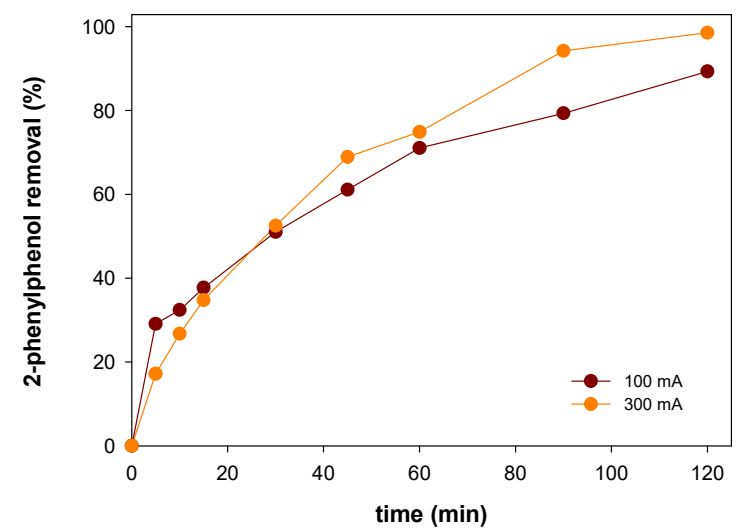

(b)

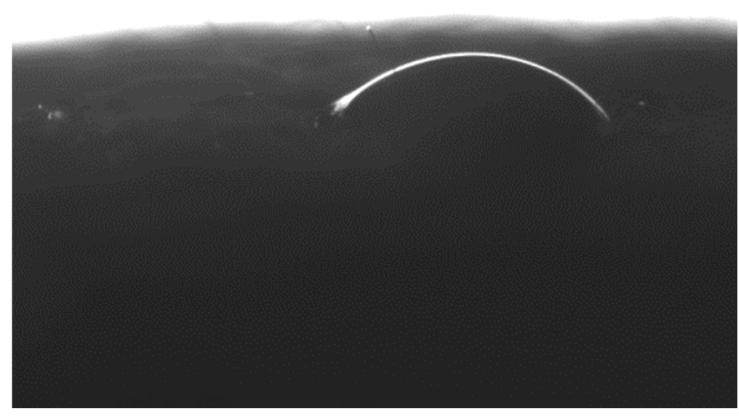

(d)

Figure 7. Profiles of hydrogen peroxide (a) and 2-phenylphenol removal (b) using the optimized electrocatalyst in electroFenton-like process at $100 \mathrm{~mA}$ (marron) and $300 \mathrm{~mA}$ (orange) and current efficiency evolution along time (c). Water contact angle determined by drop assay (d). 
This cathode provides an increase until more than 4 times de produced hydrogen peroxide after $60 \mathrm{~min}$. This behaviour can be partially explained by the measurement of the hydrophilic characteristics related to the electrode using water-drop contact angle experiments (Figure $6 \mathrm{~d}$ ). The water-drop contact angle of the electrode was $36.6^{\circ}$, which decreased from the unmodified CF $\left(133.25^{\circ}\right)$. This small contact angle implies a good hydrophilic characteristic of the optimized electrode toward the solution and changing the surface of the material. Figure $6 a, b$ illustrate the changes in the electrode surface. Higher hydrophilicity enhances the diffusion of the dissolved oxygen through the electrode suggesting an increase in the generation of hydrogen peroxide as it was detected [33]. In addition, high degradation levels were obtained with near-complete degradation after $2 \mathrm{~h}$. Although the experiment carried out at $300 \mathrm{~mA}$ with the optimized electrocatalyst achieves higher levels, taking into account its energy consumption $(4655.92 \mathrm{kWh} / \mathrm{kg}$ of 2-phenylphenol removal) the operation at high current intensity could be considered inefficient, since operating at $100 \mathrm{~mA}$ the consumption drops to $622.75 \mathrm{kWh} / \mathrm{kg}$. Those results are also confirmed by the determination of the current efficiencies (Figure 7c) showing that the operation at a higher intensity decreases the efficiency of the electrodes.

Thus, operating at the minimum current intensity the energetic consumption decreased 7.5 times with a minimal impact on process effectiveness that was around a $10 \%$ decrease from optimal efficiency. Similar results have been determined in previous studies using different electrocatalysts, such as carbon felt cathodes modified by the inclusion of nano- $\mathrm{Fe}_{3} \mathrm{O}_{4}$. Operating over a wide range of conditions, it was concluded that operating at the lowest applied current resulted in a tenfold decrease in energy consumption within a decrease in optimum efficiency of less than 10\% [64].

\section{Conclusions}

In the present study, the preparation of new catalysts and electrocatalysts using a transition metal as nickel supported in different clay and carbonaceous materials were successfully performed. Their evaluation on the degradation of a pollutant such as a fungicide 2-phenylphenol proved their efficiency and feasibility for their use in a heterogeneous Fenton based process. However, it is concluded the superiority of heterogeneous nickel electrocatalyst synthesised by the inclusion of nanofibers doped with nickel into carbon felt. The preparation of this electrocatalyst adding carbon black, nickel doped nanofibers and PTFE to the carbon felt increased significantly the potential to produce hydrogen peroxide (more than 4 times the unmodified carbon felt). In addition, the presence of the nickel catalyst on the cathode favoured the expected generation of hydroxyl radicals. The optimisation of the ratios among carbon black, nickel doped nanofibers and PTFE allowed concluding that the best production of hydrogen peroxide and the degradation yields were attained when the amount of carbon black and nanofibers were increased while the added PTFE decreased in the range evaluated. Moreover, an increase in the current efficiency and reduction in energy consumption was also achieved when a current intensity was $100 \mathrm{~mA}$. Thus, the heterogeneous nickel electrocatalyst shows an excellent behaviour in the electro-Fenton process, with high hydrogen peroxide production, pollutant removal and stability. Summing up, the use of this new electrocatalyst can be an alternative to the current cathodes that increase the catalogue of catalysts offering advantages such as low leaching, high stability and pollutants removal. These open the possibility to develop more effective electrocatalysts extending the type of catalysts in the electro-Fenton process that helps to increase the viability of electro-advanced oxidation processes showing high potential to be used in the removal of pollutants. In a future more investigations are requested in order to evaluate its behaviour in the operation at high scale. 
Author Contributions: Conceptualization, E.R. and M.Á.S.; methodology, E.R. and M.Á.S.; formal analysis, A.F.-S. and E.R.; investigation, R.M.-T. and A.F.-S.; resources, M.P. and M.Á.S.; data curation, A.F.-S. and E.R.; writing-original draft preparation, A.F.-S.; writing-review and editing, E.R. and M.Á.S.; visualization, A.F.-S., M.P. and M.Á.S.; supervision, M.P. and M.Á.S.; project administration, M.P. and M.Á.S.; funding acquisition, M.Á.S. All authors have read and agreed to the published version of the manuscript.

Funding: This research is part of the R\&D Project CTM 2017-87326-R funded by 10.13039/5011000110 33/FEDER “Una manera de hacer Europa”, Project PID2020-113667GB-I00 funded by MCIN/AEI/ 10.13039/501100011033 and PDC2021-121394-I00 funded by MCIN/AEI/10.13039/501100011033 and by the European Union Next GenerationEU/PRTR, and Xunta de Galicia and European Regional Development Fund (ED431C 2021-43). Antía Fdez-Sanromán acknowledges the University of Vigo for training fellowships.

Institutional Review Board Statement: Not applicable.

Informed Consent Statement: Not applicable.

Conflicts of Interest: The authors declare no conflict of interest. The funders had no role in the design of the study; in the collection, analyses, or interpretation of data; in the writing of the manuscript, or in the decision to publish the results.

\section{References}

1. El Balkhi, S.; Dulaurent, S.; Saint-Marcoux, F. Analytical Strategies to Measure Herbicide Active Ingredients and their Metabolites; Elsevier Inc.: Amsterdam, The Netherlands, 2021; ISBN 9780128236741.

2. Visconti, V.; Coton, E.; Rigalma, K.; Dantigny, P. Effects of disinfectants on inactivation of mold spores relevant to the food industry: A review. Fungal Biol. Rev. 2021, 38, 44-66. [CrossRef]

3. Bocos, E.; Fernandez-Costas, C.; Pazos, M.; Sanroman, M.A. Removal of PAHs and pesticides from polluted soils by enhanced electrokinetic-Fenton treatment. Chemosphere 2015, 125, 168-174. [CrossRef] [PubMed]

4. United States Environmental Protection Agency. Reregistration Eligibility Decision for 2-Phenylphenol and Salts (Orthophenylphenol or OPP). 2006. Available online: https:/ / nepis.epa.gov/Exe/ZyPURL.cgi?Dockey=P1009GW3.txt (accessed on 3 December 2021).

5. Hou, J.; Li, X.; Li, J.; Sun, J.; Zheng, S. Enhanced adsorption of o-phenylphenol on zeolites: A combing pore filling and hydrophobic effects. Microporous Mesoporous Mater. 2020, 294, 109860. [CrossRef]

6. Hou, J.; Yang, S.; Wan, H.; Fu, H.; Qu, X.; Xu, Z.; Zheng, S. Highly effective catalytic peroxymonosulfate activation on N-doped mesoporous carbon for o-phenylphenol degradation. Chemosphere 2018, 197, 485-493. [CrossRef]

7. Wang, H.; Deng, W.; Shen, M.; Yan, G.; Zhao, W.; Yang, Y. A laccase Gl-LAC-4 purified from white-rot fungus Ganoderma lucidum had a strong ability to degrade and detoxify the alkylphenol pollutants 4-n-octylphenol and 2-phenylphenol. J. Hazard. Mater. 2021, 408, 124775. [CrossRef] [PubMed]

8. Agüera, A.; Fernández-Alba, A.R.; Piedra, L.; Mézcua, M.; Gómez, M.J. Evaluation of triclosan and biphenylol in marine sediments and urban wastewaters by pressurized liquid extraction and solid phase extraction followed by gas chromatography mass spectrometry and liquid chromatography mass spectrometry. Anal. Chim. Acta 2003, 480, 193-205. [CrossRef]

9. Bolz, U.; Hagenmaier, H.; Ko, W. Phenolic xenoestrogens in surface water, sediments, and sewage sludge from BadenWürttemberg, south-west Germany. Environ. Pollut. 2001, 115, 291-301. [CrossRef]

10. Chafi, S.; Azzouz, A.; Ballesteros, E. Occurrence and distribution of endocrine disrupting chemicals and pharmaceuticals in the river Bouregreg (Rabat, Morocco). Chemosphere 2022, 287, 132202. [CrossRef]

11. World Health Organization. 2-Phenylphenol in Drinking-water. In Background Document for Development of WHO Guidelines for Drinking-Water Quality; (WHO/SDE/WSH/03.04/69); World Health Organization: Geneva, Switzerland, 2011; Volume 216, pp. 303-304.

12. Nougadère, A.; Sirot, V.; Cravedi, J.; Vasseur, P.; Feidt, C.; Fussell, R.J.; Hu, R.; Leblanc, J.; Jean, J.; Rivière, G.; et al. Dietary exposure to pesticide residues and associated health risks in infants and young children-Results of the French infant total diet study. Environ. Int. 2020, 137, 105529. [CrossRef] [PubMed]

13. Erdemli köse, S.B.; Kocasari, F. Toxicity of Ortho-Phenylphenol (OPP) and Sodyum Ortho-Phenylphenate (SOPP). Mehmet Akif Ersoy Üniversitesi Sağllk Bilimleri Enstitüsü Dergisi 2020, 8, 18-29. [CrossRef]

14. Additives, F. Novel sequential separation and determination of a quaternary mixture of fungicides by using an automatic fluorimetric optosensor. Food Addit. Contam. Part A 2019, 36, 278-288. [CrossRef]

15. Brillas, E.; Garcia-segura, S. Benchmarking recent advances and innovative technology approaches of Fenton, photo-Fenton, electro-Fenton, and related processes: A review on the relevance of phenol as model molecule. Sep. Purif. Technol. 2020, 237, 116337. [CrossRef]

16. Xian, G.; Kong, S.; Li, Q.; Zhang, G.; Zhou, N. Synthesis of Spinel Ferrite $\mathrm{MFe}_{2} \mathrm{O}_{4}(\mathrm{M}=\mathrm{Co}, \mathrm{Cu}, \mathrm{Mn}$, and Zn) for Persulfate Activation to Remove Aqueous Organics: Effects of M-Site Metal and Synthetic Method. Front. Chem. 2020, 8, 177. [CrossRef] [PubMed] 
17. Yang, Y.; Li, X.; Zhou, C.; Xiong, W.; Zeng, G. Recent advances in application of graphitic carbon nitride-based catalysts for degrading organic contaminants in water through advanced oxidation processes beyond photocatalysis: A critical review. Water Res. 2020, 184, 116200. [CrossRef] [PubMed]

18. Rekhate, C.V.; Srivastava, J.K. Recent advances in ozone-based advanced oxidation processes for treatment of wastewater- A review. Chem Eng. J. Adv. 2020, 3, 100031. [CrossRef]

19. Antiñolo, L.; Mart, J.; Muñio, M.; Manuel, J.; Capilla, P. Effectiveness of Advanced Oxidation Processes in Wastewater Treatment: State of the Art. Water 2021, 13, 2094. [CrossRef]

20. Rosales, E.; Pazos, M.; Sanromán, M.A. Advances in the Electro-Fenton Process for Remediation of Recalcitrant Organic Compounds. Chem. Eng. Technol. 2012, 35, 609-617. [CrossRef]

21. Meijide, J.; Rosales, E.; Pazos, M.; Sanromán, M.A. p-Nitrophenol degradation by electro-Fenton process: Pathway, kinetic model and optimization using central composite design. Chemosphere 2017, 185, 726-736. [CrossRef]

22. Dave, S.; Das, J. 2-Technological Model on Advanced Stages of Oxidation of Wastewater Effluent from Food Industry; Elsevier Inc.: Amsterdam, The Netherlands, 2021; ISBN 9780128210116.

23. Li, Y.; Dong, H.; Li, L.; Tang, L.; Tian, R.; Li, R.; Chen, J. Recent advances in waste water treatment through transition metal sulfides-base d advance d oxidation processes. Water Res. 2021, 192, 116850. [CrossRef]

24. Fiorenza, R.; Di, A.; Cantarella, M.; Gulino, A.; Spitaleri, L.; Privitera, V.; Impellizzeri, G. Molecularly imprinted N-doped TiO 2 photocatalysts for the selective degradation of o-phenylphenol fungicide from water. Mater. Sci. Semicond. Process. 2020, 112, 105019. [CrossRef]

25. Bouzayani, B.; Rosales, E.; Pazos, M.; Elaoud, S.C.; Sanromán, M.A. Homogeneous and heterogeneous peroxymonosulfate activation by transition metals for the degradation of industrial leather dye. J. Clean Prod. 2019, 228, 222-230. [CrossRef]

26. Wang, X.; Zhang, X.; Dai, L.; Guo, H.; Shi, P.; Min, Y.; Xu, Q. Recycling the Cathode Scrap of Spent Lithium-Ion Batteries as an Easily Recoverable Peroxymonosulfate Catalyst with Enhanced Catalytic Performance. ACS Sustain. Chem. Eng. 2020, 8 , 11337-11347. [CrossRef]

27. Dang, S.; Zhou, P.; Shi, P.; Min, Y.; Xu, Q. In Situ Aluminothermic Reduction Induced by Mechanochemical Activation Enhances the Ability of the Spent LiCoO 2 Cathode to Activate Peroxymonosulfate. ACS Sustain. Chem. Eng. 2021, 9, 15375-15385. [CrossRef]

28. Fernández de Dios, M.Á.; Rosales, E.; Fernández-Fernández, M.; Pazos, M.; Sanromán, M.Á. Degradation of organic pollutants by heterogeneous electro-Fenton process using Mn-alginate composite. J. Chem. Technol. Biotechnol. 2015, 90, 1439-1447. [CrossRef]

29. Ismail, S.A.; Ang, W.L.; Mohammad, A.W. Electro-Fenton technology for wastewater treatment: A bibliometric analysis of current research trends, future perspectives and energy consumption analysis. J. Water Process. Eng. 2021, 40, 101952. [CrossRef]

30. Ganiyu, S.O.; Zhou, M.; Martínez-Huitle, C.A. Heterogeneous electro-Fenton and photoelectro-Fenton processes: A critical review of fundamental principles and application for water/wastewater treatment. Appl. Catal. B Environ. 2018, 235, 103-129. [CrossRef]

31. Poza-Nogueiras, V.; Rosales, E.; Pazos, M.; Angeles, M. Chemosphere Current advances and trends in electro-Fenton process using heterogeneous catalysts e A review Ver o Sanrom a. Chemosphere 2018, 201, 399-416. [CrossRef]

32. Ganiyu, S.O.; Huong Le, T.X.; Bechelany, M.; Esposito, G.; Van Hullebusch, E.D.; Oturan, M.A.; Cretin, M. A hierarchical CoFe-layered double hydroxide modified carbon-felt cathode for heterogeneous electro-Fenton process. J. Mater. Chem. A 2017, 5 , 3655-3666. [CrossRef]

33. Fdez-Sanromán, A.; Acevedo-García, V.; Pazos, M.; Sanromán, M.Á.; Rosales, E. Electrochimica Acta Iron-doped cathodes for electro-Fenton implementation: Application for pymetrozine degradation. Electrochim. Acta 2020, 338, 1-11. [CrossRef]

34. Popescu, M.; Sandu, C.; Rosales, E.; Pazos, M.; Lazar, G.; Sanromán, M.Á. Evaluation of different cathodes and reaction parameters on the enhancement of the electro-Fenton process. J. Electroanal. Chem. 2018, 808, 455-463. [CrossRef]

35. Olak-kucharczyk, M.; Ledakowicz, S. Advanced oxidation of preservative agents in $\mathrm{H}_{2} \mathrm{O}_{2}$ /UVC system-Kinetics study, transformation products and toxicity assessment. J. Hazard. Mater. 2017, 333, 348-357. [CrossRef]

36. Quiñones, D.H.; Rey, A.; Álvarez, P.M.; Beltrán, F.J.; Li Puma, G. Boron doped TiO2 catalysts for photocatalytic ozonation of aqueous mixtures of common pesticides: Diuron, o-phenylphenol, MCPA and terbuthylazine. Appl. Catal. B Environ. 2015, 178, 74-81. [CrossRef]

37. Acevedo-García, V.; Rosales, E.; Puga, A.; Pazos, M.; Sanromán, M.A. Synthesis and use of efficient adsorbents under the principles of circular economy: Waste valorisation and electroadvanced oxidation process regeneration. Sep. Purif. Technol. 2020, 242, 116796. [CrossRef]

38. Soltani, R.D.C.; Rezaee, A.; Khataee, A.R.; Godini, H. Electrochemical generation of hydrogen peroxide using carbon black-, carbon nanotube-, and carbon black/carbon nanotube-coated gas-diffusion cathodes: Effect of operational parameters and decolorization study. Res. Chem. Intermed. 2013, 39, 4277-4286. [CrossRef]

39. Zhou, W.; Meng, X.; Rajic, L.; Xue, Y.; Chen, S.; Ding, Y.; Kou, K.; Wang, Y.; Gao, J.; Qin, Y.; et al. "Floating" cathode for efficient $\mathrm{H} 2 \mathrm{O} 2$ electrogeneration applied to degradation of ibuprofen as a model pollutant. Electrochem. Commun. 2018, 96, 37-41. [CrossRef]

40. Sellers, R.M. Spectrophotometric determination of hydrogen peroxide using potassium titanium(IV) oxalate. Analyst 1980, 105, 950-954. [CrossRef]

41. Zhang, Q.; Zhou, M.; Ren, G.; Li, Y.; Li, Y.; Du, X. Highly efficient electrosynthesis of hydrogen peroxide on a superhydrophobic three-phase interface by natural air diffusion. Nat. Commun. 2020, 11, 1731. [CrossRef] 
42. Hargreaves, J.S.J.; Chung, Y.; Ahn, W.; Hisatomi, T.; Domen, K.; Kung, M.C.; Kung, H.H. Applied Catalysis A, General Minimizing energy demand and environmental impact for sustainable $\mathrm{NH}_{3}$ and $\mathrm{H}_{2} \mathrm{O}_{2}$ production-A perspective on contributions from thermal, electro-, and photo-catalysis. Appl. Catal. A Gen. 2020, 594, 117419. [CrossRef]

43. Lim, J.; Hoffmann, M.R. Substrate oxidation enhances the electrochemical production of hydrogen peroxide. Chem. Eng. J. 2019, 374, 958-964. [CrossRef]

44. Nidheesh, P.V.; Gandhimathi, R.; Velmathi, S.; Sanjini, N.S. Magnetite as a heterogeneous electro Fenton catalyst for the removal of Rhodamine B from aqueous solution. RSC Adv. 2014, 4, 5698-5708. [CrossRef]

45. Olak-Kucharczyk, M.; Ledakowicz, S. Decomposition of Phenylphenol Isomers by UVC-Enhanced Ozonation Process. Ozone Sci Eng. 2017, 39, 333-342. [CrossRef]

46. Puga, A.; Rosales, E.; Pazos, M.; Sanromán, M.A. Prompt removal of antibiotic by adsorption/electro-Fenton degradation using an iron-doped perlite as heterogeneous catalyst. Process. Saf. Environ. Prot. 2020, 144, 100-110. [CrossRef]

47. Díez, A.M.; Pazos, M.; Sanromán, M.A. Bifunctional floating catalyst for enhancing the synergistic effect of LED-photolysis and electro-Fenton process. Sep. Purif. Technol 2020, 230, 115880. [CrossRef]

48. Fdez-Sanromán, A.; Pazos, M.; Rosales, E.; Sanromán, M.A. Applied sciences Unravelling the Environmental Application of Biochar as Low-Cost Biosorbent: A Review. Appl. Sci. 2020, 10, 7810. [CrossRef]

49. Kim, J.R.; Huling, S.G.; Kan, E. Effects of temperature on adsorption and oxidative degradation of bisphenol A in an acid-treated iron-amended granular activated carbon. Chem. Eng. J. 2015, 262, 1260-1267. [CrossRef]

50. Sharma, G.; Thakur, B.; Kumar, A.; Naushad, M.; Vo, D.V.N.; Al-Misned, F.A.; El-Serehy, H.A.; Stadler, F.J. Ag0-Ag2O embedded nanocomposite hydrogel for adsorption-coupled-photocatalytic removal of triclosan. Mater. Lett. 2020, 276, 128169. [CrossRef]

51. Sheng, Y.; Wei, Z.; Miao, H.; Yao, W.; Li, H.; Zhu, Y. Enhanced organic pollutant photodegradation via adsorption/photocatalysis synergy using a 3D g-C3N4/TiO2 free-separation photocatalyst. Chem. Eng. J. 2019, 370, 287-294. [CrossRef]

52. Xie, J.; Chen, L.; Luo, X.; Huang, L.; Li, S.; Gong, X. Degradation of tetracycline hydrochloride through efficient peroxymonosulfate activation by $\mathrm{B}, \mathrm{N}$ co-doped porous carbon materials derived from metal-organic frameworks: Nonradical pathway mechanism. Sep. Purif. Technol. 2022, 281, 119887. [CrossRef]

53. Bañuelos, J.A.; Rodríguez, F.J.; Manríquez Rocha, J.; Bustos, E.; Rodríguez, A.; Cruz, J.C.; Arriaga, L.G.; Godínez, L.A. Novel electro-fenton approach for regeneration of activated carbon. Environ. Sci. Technol. 2013, 47, 7927-7933. [CrossRef]

54. Bury, N.A.; Mumford, K.A.; Stevens, G.W. The electro-Fenton regeneration of Granular Activated Carbons: Degradation of organic contaminants and the relationship to the carbon surface. J. Hazard. Mater. 2021, 416, 125792. [CrossRef] [PubMed]

55. Puga, A.; Pazos, M.; Rosales, E.; Sanromán, M.A. Electro-reversible adsorption as a versatile tool for the removal of diclofenac from wastewater. Chemosphere 2021, 280, 130778. [CrossRef]

56. Puga, A.; Rosales, E.; Sanromán, M.A.; Pazos, M. Environmental application of monolithic carbonaceous aerogels for the removal of emerging pollutants. Chemosphere 2020, 248, 125995. [CrossRef]

57. Jung, E.; Shin, H.; Lee, B.H.; Efremov, V.; Lee, S.; Lee, H.S.; Kim, J.; Hooch Antink, W.; Park, S.; Lee, K.S.; et al. Atomic-level tuning of Co-N-C catalyst for high-performance electrochemical H2O2 production. Nat. Mater. 2020, 19, 436-442. [CrossRef]

58. Li, L.; Tang, C.; Zheng, Y.; Xia, B.; Zhou, X.; Xu, H.; Qiao, S.Z. Tailoring Selectivity of Electrochemical Hydrogen Peroxide Generation by Tunable Pyrrolic-Nitrogen-Carbon. Adv. Energy Mater. 2020, 10, 2000789. [CrossRef]

59. Yu, F.; Zhou, M.; Yu, X. Cost-effective electro-Fenton using modified graphite felt that dramatically enhanced on $\mathrm{H} 2 \mathrm{O} 2$ electrogeneration without external aeration. Electrochim. Acta 2015, 163, 182-189. [CrossRef]

60. Pérez, J.F.; Sáez, C.; Llanos, J.; Cañizares, P.; López, C.; Rodrigo, M.A. Improving the Efficiency of Carbon Cloth for the Electrogeneration of H2O2: Role of Polytetrafluoroethylene and Carbon Black Loading. Ind. Eng. Chem. Res. 2017, 56, 12588-12595. [CrossRef]

61. Liu, K.; Yu, J.C.C.; Dong, H.; Wu, J.C.S.; Hoffmann, M.R. Degradation and Mineralization of Carbamazepine Using an ElectroFenton Reaction Catalyzed by Magnetite Nanoparticles Fixed on an Electrocatalytic Carbon Fiber Textile Cathode. Environ. Sci. Technol. 2018, 52, 12667-12674. [CrossRef]

62. Zhu, Y.; Deng, F.; Qiu, S.; Ma, F.; Zheng, Y.; Gao, L. A self-sufficient electro-Fenton system with enhanced oxygen transfer for decontamination of pharmaceutical wastewater. Chem. Eng. J. 2022, 429, 132176. [CrossRef]

63. Li, L.; Yang, T.; Li, Z. Parameter optimization and yield prediction of cathode coating separation process for direct recycling of end-of-life lithium-ion batteries. RSC Adv. 2021, 11, 24132-24136. [CrossRef]

64. Kalantary, R.R.; Farzadkia, M.; Kermani, M.; Rahmatinia, M. Heterogeneous electro-Fenton process by Nano-Fe3O4 for catalytic degradation of amoxicillin: Process optimization using response surface methodology. J. Environ. Chem Eng. 2018, 6, 4644-4652. [CrossRef] 